\title{
Virtual analysis as a way of inclusion of the elderly in ergonomic testing
}

\author{
Mayara Ramos, Alexandre Amorim dos Reis \\ University of the State of Santa Catarina \\ e-mails: mayara.ramos@gmail.com; alexandre.reis@pq.cnpq.br
}

\begin{abstract}
The aging process causes biological, psychological, and social changes that affect the use of some products by the elderly population. The present study was carried out through a bibliographic review that aimed to demonstrate how the growth of the senior population, and the demographic changes, generated new concerns and design requirements for new products due to the consequences of aging. This scenario can somehow be met with the inclusion of this public in ergonomic testing. Virtual tests, with digital human modeling, are being more frequently used because they present reduced time and cost on the design project. The use of testing with this type of software can be an alternative to perform ergonomic tests with the elderly and others that do not fit the standard concept; HADRIAN is a virtual ergonomic testing tool that matches this solution. In conclusion, it is observed that the platforms of virtual ergonomic analysis are of low cost and good performance, and can improve the development of projects for this population.
\end{abstract}

Keywords: population aging; ergonomic testing; digital human modeling.

\section{Introduction}

Age is an important variable in the design considerations in research and practice of human factors. That happens mainly for three factors: the number of seniors in developed countries is higher than ever and continues to grow; there are critical differences related to age between young adults and older adults that need specific considerations of design; and the constant growth of the proportion of older adults in the global work force and of all users of product systems (NICHOLS; ROGERS; FISK, 2006).

In 1950 there were about 204 million elder people in the world, in 1998 that number came to 579 million, representing an increase of nearly 8 million of elder people per year. It is estimated that in 2050 the elderly population of the planet will reach 1900 million (ANDREWS, 2000).

The acceleration of the population aging and the resulting demographic changes will have a big influence on the innovation management and on the development of new products in all industrial segments. Products and services need to be adapted or new products need to be developed to better provide the necessary changes and demands of a population in aging process (KOHLBACHER; HERSTATT; SCHWEISFURTH, 2010).

Design for human disabilities and aging is frequently seen as a separate market. Although there are special products and assistive technologies for people with disabilities, they represent a little amount of all the products that need to be designed to supply the population with functional limitations. Although it may seem as a small part of the population, the groups of all disabilities represent $20 \%$ of the population. About $64 \%$ of those who live beyond 75 years old will present functional limitations and $41 \%$ of them will have severe functional limitation, many of these people will go through multiple functional limitations (VANDERHEIDEN, 2006).

The capabilities and limitations of the elderly population should be comprehended and taken over consideration on the design process and on the research on human factors to guarantee that this segment of the population may interact with products and systems in a safe, efficient, and effective way (NICHOLS; ROGERS; FISK, 2006).

Along the aging process, psychomotor, perceptual, and cognitive skills tend to decay. While the technological innovation has extended the lifetime, we find little effort to develop technologies that make up for the losses of abilities (HIGGINS; GLASGOW, 2012).

The usability can be an indicator of how intuitive is the use of a product and is one of the quality attributes noticeable to the users. This feature is determinant on the success of a product, it influences directly the user interest to use the product. The usability is a product's essential quality attribute by the time factor. In general, people become dissatisfied, frustrated and even angry, when they aren't able to execute the activity in an easy and fast way (SILVA FILHO, 2010).

Products' ergonomic tests with the inclusion of the senior population is a step forward to improve the integration of this public with the products launched on the market and follow their physical limitation caused by aging.

According to Nemeth (2004), simulation is used to preview systems or part of systems that do not exist yet and 
allow the users to experience these systems or part of them that are dangerous, complex and expensive. Solutions may be examined, evaluated and optimized with low cost and less risk to the people involved through simulation.

Through a bibliographic review, this paper intends to present the context of the elderly, and how aging affects the use of products, making it difficult to use. Also will be shown how the ergonomic analysis in virtual platforms can be an advantageous way to include in ergonomic testing parts of the population that don't fit the commercial standard, such as the elderly.

\section{Aging and the senior user}

The World Health Organization - WHO - defines the elder population as those aged over 60 years old, that been this limit for developing countries, going up to aged over 65 years old for developed countries (INSTITUTO..., 2002).

The term aging is used to talk about a process or set of processes that happen in life organisms, which over time causes loss of adaptability, functional disability, and, lastly, death. Aging is a logical extension of the physiological processes of growth and development (SPIRDUSO, 2005).

Aging is the inscription of time in each individual. It is pronounced by biological, psychological and social transformations on extreme ages. These transformations occur in three temporal dimensions: individual history, generations' evolution and work and society's evolution. Therefore, variability and diversity in the same generation and the ones that follow are substantial. The interindividual differences rise with age: the chronological age does not handle the functional age (FALZON, 2007).

The theory over aging, stochastic theory, suggests that the loss of functionality that occurs on aging is caused by the random accumulation of lesions in vital molecules, associated to environmental action, which causes a progressive physiological decline (AVERSI-FERREIRA; RODRIGUES; PAIVA, 2008).

To live longer increases in $80 \%$ the probability of contracting one or more chronic diseases, as well as striking physical limitations. In many cases it is difficult to distinguish when the changes are a consequence of the aging process or when they are pathological manifestations (HOEMAN, 2000 apud AVERSI-FERREIRA; RODRIGUES; PAIVA, 2008).

Although most of the elderly is diagnosed with at least one chronic disease, they limit not all of them, many of them live a completely normal life with their illness controlled. An elder with chronic diseases may be considered a healthy elder, if compared with an elder with the same diseases, but with no control of them, with the consequences and inabilities associated. Thus, the concept of health from WHO shows itself to be unfit to describe the health universe of the elderly, once the absence of diseases is a privilege of few, and many, regardless of the presence or not of diseases, may achieve the complete well-being (RAMOS, 2003).

To develop a product that is functional, efficient, safe and engaging, that increases the abilities or compensate the user limitations, is necessary to consider what is known about the changes that occur on the senses and physical capabilities during aging, and review the published design guidelines. The user of a product needs to see it, understands it, possibly hears it and probably handles it someway, consequently the most relevant physical capabilities to be considered are vision, hearing and manual functions (HAIGH, 1993).

The beginning and the speed of aging process depend on the person, depending on the birth decade, health, eating habits, exercise, work and social activities throughout life (HAIGH, 1993).

The changes related to age on body dimensions and composition do not stop. The body composition, bones, fat and muscles mainly, absolute and relatively change; the joint range of motion is affected by time and disuse (SPIRDUSO, 2005).

The changes of aging, according to Nichols, Rogers and Fisk (2006), may be classified in:

- Perception: vision, hearing;

- Movement control and biomechanics: movement speed, movement control, balance, locomotion, strength, strength control;

- Cognitive process: attention, memory;

- Language: sentence structure, interface, and figurative language;

- Motivational: believes and attitudes.

Tilley and Dreyfuss (2005) point out that tall elder men lose $5 \%$ of their height, compared to their heights in their $20 \mathrm{~s}$; short elder women lose $6 \%$ of their height. Among the factors that influence this fact is the loss of $10 \mathrm{~mm}$ growth per decade and their cartilage shrink, especially on the spinal cord. The posture of the elderly also tends to be worse.

Still according to the authors the hands' strength is reduced about $16-40 \%$, limbs' strength decline about 50\%, lung capacity decreases about $35 \%$, most of the body dimensions decreases with the increasing age, nose and ears grow in width and length, the weight may increase $2 \mathrm{Kg}$ every ten years.

\section{Simulation and virtual ergonomic analysis}

Computer-aided engineering (CAE) and computeraided design softwares allow three-dimensional design and modeling solid objects, enabling functional analysis and product and systems simulation (SUNDIN; ÖRTENGREN, 2006). Due the increasing use of these softwares, lately experts on human factors and ergonomics are being called to participate on the early stages of the design processes. The early participation in these disciplines results in better and more integrated projects, including lower costs. The 
experts in human factor and ergonomics main objective should be providing well-based inputs towards human, their interaction with the system, and the resulting performance (LAUGHERY; LEBIERE; ARCHER, 2006).

According to the authors, to achieve overall performance, many human factors and ergonomics' tools and technologies have been improving through the years to help anticipate analysis and design. Such as many engineering areas, an excellent candidate to this interactions is computer modeling and simulation.

Digital human modeling (DHM) and virtual human simulation were created to facilitate help ergonomic analysis (MA et al., 2009). DHM represents the technology of using a computer to build a virtual representation of a person to simulate movements and human strain (CHAFFIN, 2001 apud WU; TIAN; DUFFY, 2012). Virtual human simulation provides a quick virtual representation of humans in a simulated work environment (CHAFFIN; ERIG, 1991 apud HU et al., 2011).

Chaffin (2005 apud WU; TIAN; DUFFY, 2012) summarizes the present-day digital human modeling (DHM) based ergonomic analysis as a model that includes environment, population data, task, human movement as input to generate the digital manikin movement, that may give as result the information of adjust/adaptation of interference, line of sight, and time on task. The ergonomic evaluation may be applied based on the digital manikin movement to provide results such as strength, balance, resistance, risk of injury, and discomfort.

The incorporation of a digital model that simulates human actions on the product design process has been recognized as highly effective on the development of products designs that are users' centered. The designer may have the feedback of the consumer based on a digital model that simulates the human behavior, both physical and psychological on the initial concept stage of design. Still, the digital human may present useful information such as biotype, dimensions, movement restrictions, and operational sequence in a tridimensional space that must be considerate on the detailing of the design. Represented by the manikin, the final user can interact with a product's model, helping the customization of the product as the project develops (KUO; CHU, 2005).

The high diversity of users, the role that is occupying and the performed activity highlight the need to use digital human models on the development of products and work stations. Digital representation of humans has become more common. The development of DHM tools began on the 1960s and has earned attention in recent years, generating an improvement in content, utility, and ability to solve softwares' problems (SUNDIN; ÖRTENGREN, 2006).

The firsts DHM software were mainly used to graphic animation. Its applications have widely increased, today is used primarily to industrial purpose, also being used to consumer and/or user problems. The primal objective of the software is to promote anthropometric support: analysis, measurements, product design and production evaluation, visually analyzing reach, vision and others, before any physical object is built (JUNG et al., 2009; SUNDIN; ÖRTENGREN, 2006).

\section{Virtual analysis and the elderly}

According to Sundin and Örtengren (2006), the attempt of digitally represent the complexity of the human being, the functions being modeled include both physical execution and cognitive aspects. Tilley and Dreyfuss (2005) say that the 3D human modeling has the main advantage of running tasks of ergonomic measuring that with the use of traditional anthropometric data would be extremely complicated.

Although the studies have contributed to the development of digital human models, appropriated methods to human modeling for CAD systems still don't exist regarding dimension precision and results reliability (BAEK; LEE, 2012). The use of human modeling in CAD systems normally involves the construction of 3D human models using published anthropometric data or from corporal scanning, and after interactively evaluate if these models may fit, reach and see in the designed work station (PORTER et al., 2004). Conventional databases do not supply the amount of information required to people with special needs or those who do not fit the standard patterns (lefties, elderly and others). To simulate these individuals, it is necessary to collect a much larger number of data; it is needed to collect anthropometric data for joint length and the traditional ones such as external dimensions and scopes, it is needed to know more about the strength of all limbs to perform daily activities (PORTER et al., 2004).

Ashworth et al. (1994 apud PORTER et al., 2004) demonstrated the extension in which elderly or disabled people end up being left out of projects. The authors reported that $21 \%$ of U.S. citizens between 65 and 74 years old, and $55 \%$ of those aged above 85 years, had at least some difficulty with the management of household activities, including activities of daily living (ADLs) that are essential to personal independence to social living.

There is a need for new approaches able to support designers when they are developing a design suitable for all. Providing the designer the appropriate data about his target user is an important requirement if is desired the users' needs to be fulfilled on the product's design (PORTER et al., 2004). The authors address the collect and availability of these data having a new approach - the collection of a great range of individual data covering a wide range of ages and abilities. This differs from the population data available broadly (as percentiles tables) by providing a holistic and robust database that is ideal to complex and 
multivariate analysis that should be done to evaluate the users' capabilities (PORTER et al., 2004).

Thus, Porter et al. (2004) developed a design tool CAD based called HADRIAN - Human Anthropometric Data Requirements Investigation and Analysis, which is a multivariate database containing 3D anthropometry and functional abilities of a wide range of people, gathered with the methodology to explore the use of these data. This new approach was to create a computational database of individuals so that multivariate analysis may be conducted in a wide scale of real people of all ages, abilities and biotypes.

According to the responsible company (SAMMIE CAD, 2013), the software contains anthropometric data, joint mobility, scopes' volumes, and posture-based tasks capabilities for 100 people. Of these 100 people, most of them are older or disabled and are kept as individual in the database. These data can then be used to inform design decisions by highlighting the capability issues of individuals within the population.

In addition to the more traditional anthropometry and joint mobility measures, the database contains data capacity of tasks to a diversity of tasks in the kitchen. Interviewed older and disabled people identified kitchen tasks as being important to their life quality. The ability to perform the tasks were recorded for the database. In addition to the ability to perform a task, the way in which the task was performed was also recorded. This behavior was converted into a postural code that could be used to predict behavior for similar tasks in different situations (SAMMIE CAD, 2013).

\section{Conclusion}

As presented in this paper, DHM has gained space in the design scene for bringing advantages as time and cost reduction on the project, and for anticipating project phases, such as ergonomic analysis. These analyzes may result in data that simulate the users' response, both physical and psychological, without the need of a product prototype.

Initiatives as HADRIAN show the existing need for inclusion of the population that do not fit the standard population on the anthropometric database, the elderly population, for instance, is a growing and significant group of the population in the current consumer market.

Considering the already established use of CAD/CAE platforms to product design development, the growing use of DHM software, and the need and initiative of Porter et al. (2004) in including anthropometric data of the non-standard population; it may be suggested that the virtual ergonomic analysis platforms is a low cost and good performance alternative for improving the design delivered to the consumer market providing more comprehensively the consumer needs.

\section{References}

ANDREWS, G. A. Los desafíos del proceso de envejecimiento en las sociedades de hoy y del futuro. In: ENCUENTRO LATINOAMERICANO Y CARIBEÑO SOBRE LAS PERSONAS DE EDAD, 1999, Santiago. Anais... Santiago: CELADE, 2000. p. 247-256.

AVERSI-FERREIRA, T. A.; RODRIGUES, H. G.; PAIVA, L. R. Efeitos do envelhecimento sobre o encéfalo. Revista Brasileira de Ciências do Envelhecimento Humano, v. 5, n. 2, p. 46-64, 2008.

BAEK, S.; LEE, K. Parametric human body shape modeling framework for human-centered product design. ComputerAided Design, v. 44, n. 1, p. 56-67, 2012. http://dx.doi. org/10.1016/j.cad.2010.12.006

FALZON, P. Ergonomia. São Paulo: Blucher, 2007.

HAIGH, R. The aging process: a challenge for design. Applied ergonomics, v. 24, n. 1, p. 9-14, 1993. http://dx.doi. org/10.1016/0003-6870(93)90153-Z

HIGGINS, P. G.; GLASGOW, A. Development of guidelines for designing appliances for older persons. A Journal of Prevention, Assessment \& Rehabilitation, v. 41, n. 1, p. 333-339, 2012.

HU, B. et al. Predicting real-world ergonomic measurements by simulation in a virtual environment. International Journal of Industrial Ergonomics, v. 41, n. 1, p. 64-71, 2011. http:// dx.doi.org/10.1016/j.ergon.2010.10.001

INSTITUTO BRASILEIRO DE GEOGRAFIA E ESTATÍSTICA - IBGE. Perfil dos idosos responsáveis pelos domicílios no Brasil: 2000. Rio de Janeiro, 2002.

JUNG, M. et al. Integrated framework for vehicle interior design using digital human model. Journal Of Computer Science And Technology, v. 24, n. 6, p. 1149-1161, 2009. http://dx.doi.org/10.1007/s11390-009-9287-3

KOHLBACHER, F.; HERSTATT, C.; SCHWEISFURTH, T. Product development for the silver market. In: KOHLBACHER, F.; HERSTATT, C. The silver market phenomenon: marketing and innovation in the aging society. 2nd ed. Berlin: Springer, 2010. p. 3-13.

KUO, C.-F.; CHU, C.-H. An online ergonomic evaluator for 3D product design. Computers in Industry, v. 56, n. 5, p. 479492, 2005. http://dx.doi.org/10.1016/j.compind.2005.02.002

LAUGHERY, K. R.; LEBIERE, C.; ARCHER, S. Modeling Human Performance in Complex Systems. In: SALVENDY, G. Handbook of human factors and ergonomics. Hoboken: John Wiley \& Sons, 2006. cap. 36, p. 967-1052.

MA, L. et al. A new simple dynamic muscle fatigue model and its validation. International Journal of Industrial Ergonomics, v. 39, n. 1, p. 211-220, 2009. http://dx.doi. org/10.1016/j.ergon.2008.04.004 
NEMETH, C. P. Human factors methods for design: making systems human-centered. Boca Raton: CRC Press, 2004. http://dx.doi.org/10.1201/9780203643662

NICHOLS, T. A.; ROGERS, W. A.; FISK, A. D. Design for Aging. In: SALVENDY, G. Handbook of human factors and ergonomics. Hoboken: John Wiley \& Sons, 2006. cap. 54, p. 1418-1445.

PORTER, J. M. et al. "Beyond Jack and Jill”: designing for individuals using HADRIAN. International Journal of Industrial Ergonomics, v. 33, n. 3, p. 249-264, 2004. http:// dx.doi.org/10.1016/j.ergon.2003.08.002

RAMOS, L. R. Fatores determinantes do envelhecimento saudável em idosos residentes em centro urbano: Projeto Epidoso, São Paulo. Cadernos de Saúde Pública, v. 19, n. 3, p. 793-798, 2003. PMid:12806481. http://dx.doi. org/10.1590/S0102-311X2003000300011

SAMMIE CAD. SAMMIE Research: HADRIAN. Leicestershire. Available from: <http://www.lboro.ac.uk/ microsites/lds/sammie/reshad.htm $>$. Access in: 15 June 2013.
SILVA FILHO, A. M. Avaliação de usabilidade: "separando o joio do trigo". Revista Espaço Acadêmico, v. 10, n. 112, p. 10-14, 2010.

SUNDIN, A.; ÖRTENGREN, R. Digital human modeling for CAE applications. In: SALVENDY, G. Handbook of human factors and ergonomics. Hoboken: John Wiley \& Sons, 2006. cap. 39, p. 1053-1078.

SPIRDUSO, W. W. Dimensões físicas do envelhecimento. Barueri: Manole, 2005.

TILLEY, A. R.; DREYFUSS, H. As medidas do homem e da mulher: fatores humanos em design. Porto Alegre: Bookman, 2005.

VANDERHEIDEN, G. C. Design for people with functional limitations. In: SALVENDY, G. Handbook of human factors and ergonomics. Hoboken: John Wiley \& Sons, 2006. cap. 53, p. 1387-1417.

WU, T.; TIAN, R.; DUFFY, V. G. Performing ergonomics analyses through virtual interactive design: validity and reliability assessment. Human Factors and Ergonomics in Manufacturing \& Service Industries, v. 22, n. 3, p. 256268, 2012. http://dx.doi.org/10.1002/hfm.20267 